\title{
Improving Learners' Oral Proficiency in French Through the Communicative Approach: Colleges of Education in Oyo in Focus
}

\author{
Balogun Thomas Akanbi ${ }^{1, *}$ \& Kezie-Osuagwu Clementina Ndidi ${ }^{1}$ \\ ${ }^{1}$ Federal College of Education, Oyo, Nigeria \\ *Correspondence: Federal College of Education, Oyo, Nigeria. E-mail: baloson2002@yahoo.com
}

Received: November 24, 2019

Accepted: January 2, 2020 Online Published: February 19, 2020

doi:10.5430/jct.v9n1p55

URL: https://doi.org/10.5430/jct.v9n1p55

\begin{abstract}
It cannot be overemphasised that French language is a foreign language in Nigeria and that its teaching and learning cannot take the same process as acquiring/learning the mother tongue or a second language. Foreign language learning requires some strategic applications in order to be able to interact with the native speakers in real life day to day communication. This study aims at delving into some teaching strategies involving the communicative approach to teaching French as a foreign language in order to boost the oral proficiency of our learners in French. The teachers and students in two colleges of Education namely Federal College of Education (Special) [FCES] and Emmanuel Alayande College of Education (EACOED), both located in Oyo town, were the participants in the study. Data were collected through classroom observation, students' achievement test as well as questionnaires for teachers. The results indicated that students perform better when the teachers employ the communicative approach. Based on the findings of this study, it is therefore recommended that teachers of French language use the communicative language teaching approach to build confidence in their students as this will help to develop faster their linguistic skills, given that this approach gives priority to listening and speaking skills over reading and writing skills.
\end{abstract}

Keywords: oral proficiency, communicative approach, foreign language

\section{Introduction}

\subsection{Background to the Study}

Generally, we set out to learn a foreign language for the purpose of desiring to expand one's possibilities of communication especially with the native speakers to express our feelings and/or to resolve matters between individuals or groups (Spencer-Oatey and Žegarac, 2013, p. 81). Teaching a language generally requires the development of the mastery of that language for the purpose of communication. On the other hand however, learning a language whether a first or a foreign language like French is not an easy process. It requires efforts at developing subtle and detailed knowledge about why, how and when to communicate, and complex skills for producing some kind of interactions (Burns and Seidlhofer, 2013, p. 197). To be able to use the language in an interactive way and in any communicative activity such as taking turns at listening and speaking in conversation requires and involves more than one language skill (Schmitt and Celce-murcia, 2013, p. 13). Communicating in any language requires the mastery of the four language skills: oral comprehension, oral expression, written comprehension and written expression. Of the four language skills, oral comprehension and oral production precede the two written skills. Following the same line of reasoning, Martinet (1974, p. 56) states that the primary and fundamental manifestation of language is in the spoken language. So also, Ajiboye and Oshounniran, (2010, p. 117) affirm that even centuries before human intelligence pushed man to invent written characters, man could already speak. That is to say that speech is as old as humanity. For a long time, speech (a manifestation of oral language), was the only available means of man's integration into any given linguistic community. Every man can speak but not all men can write so any language which cannot be spoken can pass for a dead language. In consonance with Ajiboye and Oshouniran (2010, p. 117), Zhang (2013, p. 834) and Anderson (n.d., p. 97) affirm that written language is derived from oral language. For these reasons, our major concern in this study is the improvement of oral proficiency in French as a foreign language (herein after FLE) via the oral communicative approach.

Since the primary and fundamental manifestation of any language is found in the spoken language and being the first 
manifestation of communication, acquiring oral communication competence in a foreign language like French requires more attention. The oral communication class therefore helps the students improve their spoken French and to acquire and put into practice the elementary principles of interpersonal communication.

The very purpose of learning a certain language is to be able to have a good competence in speaking it so that such a person would have sufficient skills to communicate easily and possibly fluently with the native speakers. Learning French in Nigeria by our students requires that they apply skillfully the knowledge gained in the classroom for effective communication. Consequently, they need to progress by having a good grounding of the elementary skills in French language acquisition in order to be proficient in expressing their thoughts in spoken words of the language. In the same vein, empirical studies have also established the important role that oral language plays in learning (Babayiğit, 2014; Darancik, 2018; Swanson \& Schlig, 2010). As students practise listening and speaking skills, and acquire knowledge of how language works, they build not only basic literacy but problem solving and reasoning skill as well as the capacity for creative thinking. That is why the most powerful language programmes are not so much about grammar drills and translation exercises but rather about engaging students in authentic interaction and purposeful conversation (Ketch, 2005; Wells, 2007).

Proficiency is defined, according to Cambridge International Dictionary of English (1995) and Merriam-Webster (2017), as the advancement in knowledge or skill. Proficiency is further defined by www.businessdictionary.com/.../ as a "mastery of specific behavior or skill demonstrated by consistent superior performance, measured against established or popular stand". Going by these definitions, we can deduce that oral French proficiency is a student's advancement in his natural aptitude to perform beautifully or excellently in the oral practice of the language, be it in the classroom settings and/or outside the classroom. Oral proficiency, as elucidated by Stein $(1999, \mathrm{p} .1)$ includes the "ability to communicate verbally in a functional and accurate way in a target language". Oral proficiency in French language therefore includes the ability of the individual learner to exhibit his/her acquired knowledge to speak and communicate in French in a successful and skillful manner. The acquisition of communicative competence constitutes the central objective teaching and learning of French as a foreign language (Bérard, 1991; Courtillon, 2006; Aslim, 2011). Of course, when the students develop this aptitude in French, they will be able to understand and communicate very well in that language in real-life situations, most especially with the native speakers.

Among all difficulties of learning FLE in Nigeria, oral competence occupies the first position. Many reasons abound from several researches for the inability of Nigerian students to communicate in French. They include lack of intrinsic motivation on the part of the students, inadequate language laboratories and other facilities, non-provision of teaching materials in Nigeria's tertiary institutions, inadequate language immersion programmes, teachers with oral communication deficiencies, etc. (Adesola, 2007; Araromi, 2009; Emodi, 2000; Kezie-Osuagwu, 2013; Owoeye, 2010). While Simire, (2001) further observed that most French learners cannot speak French for fear of making mistakes.

A student who tries in his proficiency in a foreign language like French is such that has made efforts to try to overcome some difficulties in speaking, reading or understanding the French language rules. He would like to try as much as possible to avoid such difficulties or obstacles, if not, these could deny him/her the very opportunity to successfully learn the language in the classroom or even participate fully in communication in a real francophone setting. Oral proficiency is therefore very important to individuals learning a particular language because this describes how well such an individual can speak the language in real world situations and at all events.

Further discussion of the problems facing the teaching of French shall be made under the following categories.

The students

The teachers

The college authorities and government

The environment

The year abroad programme (acculturation)

Motivation and interest

Teaching methodology

\subsection{The Students}

The entry requirement into the colleges of education in Nigeria is very low. Even when the students have a good credit pass in French in their West African Senior School Certificate Examination (WASSCE), they are usually 
unable to communicate in the language. Thus, their paper qualifications do not reflect their knowledge and competence in French which should manifest primarily in the spoken language. With this insufficient linguistic foundation, it would be difficult to teach French in a system where their level from the secondary school does not correspond with their supposed entry level into the colleges of education owing to the fallen standard in education.

Moreover, the students often have no idea of the objectives of French studies. This is because they did not initially apply to study French but are admitted for the course because they could not satisfy the requirement for their chosen courses. For instance, in the Federal College of Education (Special), Oyo, more than one third of the students learning French fall into this category and consequently fail to do well in the course.

\subsection{The Teachers}

The role and position of the teachers are very important in the teaching of French because they can encourage or discourage the learners in their learning of the language. Unfortunately, there is a grave shortage of qualified teachers and teaching materials for the oral aspect of language learning. Therefore we find that more than half of the learners are usually very badly taught or are never truly exposed to oral communication of the language. Most of the teachers use the traditional method or the grammar-translation method to teach their students which of course results in the poor performance of students, most especially in oral communication. This is because some of the teachers themselves are unable to communicate freely in French and as such resort to teaching solely in English or the mother tongue. David (1975, p. 11) says in this respect that "often those who teach French are inadequately qualified and thus contributes to the disenchantment and to the general bad name of the subject". Therefore, to be adequately qualified to teach especially a foreign language like French in Nigeria, one needs to be well trained pedagogically to be able to properly handle well the teaching of the subject.

\subsection{The College Authority and Government}

It is in buying of audio-visual materials and financing that the authorities of an institution can be appreciated. In fact the college authority must furnish the department with all or most of the necessary teaching materials like projectors, video machines, disks, functional ICT facilities, etc. Unfortunately, the situation is rather very deplorable in Nigeria. Some colleges even have laboratories with very obsolete materials which do not function for lack of technicians and electricity. While some others have a resource room that contains only a television and video set without proper connection to electricity supply as is the case with the Federal College of Education (Special) and Emmanuel Alayande College of Education in Oyo state.

Sometimes the authorities and government totally ignore the importance of French to Nigeria and its citizens. Instead of encouraging its teaching, they advocate its extinction and close down the department as was the case of the college of education in Adamawa State not minding the state's closeness to francophone Cameroun.

\subsection{The Environment}

The students come in contact with French only in the classroom. Most of them live off campus and do not often meet to interact in the language until they are in class again. This situation is a disadvantage to the learning of French especially as a foreign language. Besides, the students of French language form only a minute percentage of the entire population in most colleges. Therefore, communication among them outside the classroom is almost nonexistent. Though there exists a French club in each of the colleges, if not all, where students can express themselves through debates, symposia, role play, comment on short and simple film shows, etc.; yet students hardly ever communicate in French during these different socio-educational activities, especially because these activities do not form part of their continuous assessment. So, they all need to be encouraged and given "opportunities for trying things out" (Dişlen, 2013, p. 43). It is crystal clear that when a classroom becomes a pseudo foreign language environment, if positive; it can determine how efficient learners could perform in oral communication (Johnson, 2012, p. 11).

\subsection{The Year Abroad Programme (Acculturation)}

The objective of the year abroad programme otherwise known as acculturation for their linguistic immersion is to improve the learner's use of French language words. Popovici (2016) postulates that the effective way one can learn a foreign language appropriately is by being in an environment where you are exposed to the new language in everyday scenarios because you are forced to learn. Learning a foreign language is about everyday routine. One cannot be at his best when such a person is given to studying textbooks attentively and memorising vocabularies. Indeed, a language immersion environment proves to be the fastest way where heterogeneous topics are authentically acquired through instructions and practices without doubt. 
However, in the past, colleges of education in Nigeria sent their students to francophone countries at the end of their 100 or 200 level. This formed part of the entire course programme and was therefore compulsory. Now, it has become difficult to send students outside the country for their linguistic immersion programme for financial reasons. Consequently, the colleges churn out French graduates who at the end of their entire National Certificate in Education (NCE) year can speak little or no French. Even though the federal government in conjunction with the French government has instituted a Nigeria French Language Village (NFLV) in Badagry, Lagos, for economic reasons, the French village can never be equated with a real francophone environment. It can only stop at continuing the academic programme but can never take care of the linguistic immersion programme.

\subsection{Motivation and Interest}

Motivation is the arousal, selection, direction and continuation of behaviour. Motivation is very important because it controls and directs our energy. It can be viewed as the most important element as far as the learning process of a foreign language is concerned (Lai, 2013, p. 90; Axell, 2007, p. 3). Unless a child is well motivated, he will not direct his energy and effort towards learning. Therefore, we agree with Bello (1982) that motivation improves learning outcome. It can gear up weary students for a desire to learn and ultimately improve the rate at which they learn a foreign language like French (Johnson, 2012, p. 14).

Motivation and interest are tools that help to achieve our goal especially in the learning of French as a foreign language (Dişlen, 2013, p. 36). However, the problem with most schools is lack of motivation on the part of both the students and teachers. Majority of students do not even know why they are studying French. They do only know that it is part of their studies. As a result, most of them play with the French word they have learnt, interchanging them with English words or with words in their mother tongue which have the same or similar sounds.

On the part of the teachers, motivation is lacking, with the deplorable and discouraging conditions of working in which they find themselves. Salaries are usually not paid on time, good materials for teaching are almost not available and only a few honed teachers who teach with their conscience do not abandon true teaching.

\subsection{Teaching Methodology}

Studies have shown that in Nigeria, the teacher tends to do all the talking while the learners simply listen all through the lesson (Balogun, 2016; Idogho, 2016). Language is living and must be interactive. So when all the teacher does is to speak and translate French to the learners, learning becomes uninteresting. This style of teaching is the traditional method where words are classified into their functions after which students are made to study a list of verbs and their conjugation. It is a method that emphasises written language to the detriment of oral language. The communicative approach has been a widely accepted convention in the field of teaching French as a foreign language in Nigeria (Balogun, 2016). The consensus is that the oral communicative approach could be applied in foreign language teaching (Isacova, 2018: Denkci Akkas \& Coker, 2016; Darancik, 2018; Fattah \& Saidalvi, 2019).

In the oral communicative approach, the four skills of language are developed. Language is considered the instrument of communication or social interaction, the reason for which teaching is based on speech acts. As communication takes place, meaning or the message is given priority while grammar and vocabulary are considered tools for the realisation of speech acts. The teacher serves as a facilitator in the class (Kezie-Osuagwu, 2017, p. 183). The learners are encouraged to spontaneously communicate among themselves. They are free to make mistakes and the mistakes form part of the learning. Corrections of errors are done at the end of the class to avoid interrupting the learners' speech flow. The learning resources are taken from real life: images, pictures, posters, magazines, television and radio programmes, etc.; these are called authentic documents meant to be consumed by native speakers, not originally fabricated for the classroom. In short the main goal of oral communication is to develop fluency in language use. In Richards' (2006, p. 14) terms, "fluency is the natural language use occurring when a speaker engages in meaningful interaction and maintains comprehensible and ongoing communication despite limitation in his or her communicative competence".

In Nigeria students learning French can only practise in the classroom whereas it is imperative that the process of skills acquisition in foreign language needs to be learnt in an environment that allows for total immersion, that is, where learners have unhindered opportunities to use the language variety in situations. It is therefore viewed that since these students are not exposed to total linguistic immersion, communicative approach will be of great didactic help.

\subsection{Statement of the Problem}

Most French classes are dominated by written work and little or no attention is given to oral work. Even during the class titled Oral Expression almost only written work is done and in English or the mother tongue too. This does not 
give the learners the possibility of developing the necessary competences for oral comprehension and production. Although the current French curriculum in the National Commission for Colleges of Education minimum standard, (NCCE, 2012) insists on the use of the communicative approach, the traditional method is still in practice by some colleagues in our French classes in the colleges of education. Thus, this investigation will be informative and provide positive changes in French teaching, especially in the teaching of oral skills.

\section{Research Hypotheses and Methodology}

\subsection{This Research Focuses on the Following Hypotheses}

Ho1: There is no difference in students' achievement when exposed to communicative approach as opposed to being restricted to traditional methods

Ho2: There is no difference in students' achievement between sampled colleges of education

\subsection{Methodology}

The study investigated the outcome of the communicative approach against other traditional or conventional methods. The study adopted the quasi-experimental design. Experimental lessons were conducted for the first year students of the two colleges in Oyo state. The rationale behind using this intact class is their relative minimal or no exposure to the French language as this assures a homogenous background of the student-participants. They were divided into two groups. The first (target group) were taught using the oral communicative approach and in the target language while the second group (control group) was taught the same lesson without the oral communicative approach or with the traditional method in English or in the learners' mother tongue. After this lesson, the students were made to undergo the same evaluation process. In the end, the students' test results and teachers' responses to a survey questionnaire on the implementation of the communicative approach were analysed.

The population used was the entire 2017/ 2018 first year students of the two colleges of education in Oyo town in Oyo state namely: Federal College of Education (Special) and Emmanuel Alayande College of Education. The total population of this Level was considered because of the low intake of French students. Other participants include the teachers of French in both colleges.

All the first year students and all the French lecturers of the two colleges in Oyo state were selected as participants in the study. The purposive sampling technique was used for selection.

Method of data analysis

The data collected were analysed using a t-test statistical technique.

\section{Results and Discussion}

\subsection{Test of Hol Hypothesis}

Ho1: Mean score difference in students' achievement when exposed to the communicative approach as against other methods.

Table 1. The Choice of Teaching Methodologies Used in the Sampled Colleges of Education

\begin{tabular}{lccccc}
\hline Variables & Mean & St.dev & Num & Tcal & Ttest \\
\hline Communicative approach & 6.86 & 1.73 & 7 & 3.917 & 0.695 \\
Traditional method & 4.0 & 2.0 & 7 & & \\
\hline
\end{tabular}

Using the t-test score, a calculated value of 3.917 was obtained against the table value of 0.695 at a degree of freedom of 12 at the significant level of 0.05 . The calculated value obtained is greater than the table value which signifies that the value could not have arisen by chance, meaning that the calculated value is significant at that specified level of significance. This therefore implies that since the calculated value was more than the table value, then the hypothesis is therefore rejected and the alternative hypothesis is retained.

There is a significant difference in the mean score of students when exposed to the communicative approach as opposed to when they are exposed to traditional methods.

Choice of methodology: There are several methods used in the teaching of French language in schools. Some of 
these methods include the audio-lingual, communicative, direct, grammar translation and other methods. As regards the choice of the use of the audio-lingual method, 4 (30.77\%) of the respondents sometimes made use of it, 3 $(23.08 \%)$ often used it, and $3(23.08 \%)$ always used the method while only $2(15.38 \%)$ rarely employed it. Going by the above submission, it was revealed that the audio-lingual method was employed by $10(76.92 \%)$ of the lecturers while only $2(15.38 \%)$ rarely used the method and $1(7.69)$ represents a missing datum.

- Direct method: With regard to the usage of the direct method in the teaching of French in colleges of education, 3 (23.08\%) always used it as a method of teaching, $2(15.38 \%)$ often used it, $6(46.15 \%)$ sometimes used it while 1 $(7.69 \%)$ rarely used the method. This shows that the use of the direct method in the teaching of French is gradually dwindling in our schools.

- Grammar Translation method: In the case of the grammar translation method, it was revealed that $2(15.38 \%)$ always used the method to teach while $1(7.69 \%)$ often used it. In the same vein $5(38.46 \%)$ sometimes used the method while $3(23.08 \%)$ rarely used it in their classes.

- Communicative approach: As regards the use of the communicative approach in the teaching of the subject, 7 $(53.85 \%)$ always used it, $4(30.77 \%)$ often used the method, while $1(7.69 \%)$ sometimes and rarely used it in their teaching. In sum, the majority of the teachers in this category often or always as the case may be, in compliance with the NCCE minimum standard requirement (2012), make use of the communicative approach in teaching their students. The submissions of the respondents show that the communicative approach gained prominence in the teaching of French language in Nigeria colleges of education as earlier indicated by Balogun (2016).

\subsection{Test of Ho2 Hypothesis}

Ho2: There is no difference in students' achievement between the sampled colleges of education

Table 2. The Mean Score Difference in Students' Achievement between Sampled Colleges of Education

\begin{tabular}{llllll}
\hline Colleges & $\mathrm{N}$ & Mean & S.D & tcal & t-table \\
\hline FCES & 6 & 14.8 & 2.4 & 1.29 & 1.782 \\
EACOED & 7 & 13.6 & 3.2 & & \\
Total & 13 & & & & \\
\hline
\end{tabular}

The value of $t$ obtained for the achievement of students in the two colleges of education used for the study showed a mean value of 14.8 for FCES, 13.6 for EACOED and their standard deviation were 2.4 and 3.2 respectively. Testing if a significant difference in the achievement of students in the colleges at $t$ value of 1.29 was obtained, being insignificant at 00.5 level because the obtained value of $t$ is lower than the table value of 1.872 at a degree of freedom of 12. With this, the hypothesis stating that there is a significant difference in the mean score test of the students is hereby retained.

i. The study showed that students' achievements do not vary with school.

ii. Students' achievement when exposed to the communicative approach differs significantly from when they are not exposed to the method. This is certified by Bérard (1991), Courtillon (2006) and Aslim (2011)'s assumption that the acquisition of communicative competence constitutes the central objective of the teaching and learning of French as a foreign language.

\section{Conclusion}

As in Nigeria, Denkci Akkas and Coker (2016) observed that in Turkey, classrooms lack meaningful communication and the students learn about the usage of the language rather than using the language as instrument to convey some kind of meaning or to accomplish a task in a meaningful way. Also, findings from the research carried out by Fattah and Saidalvi (2019) show that teachers do not fully implement the communicative language teaching as a result of their unawareness of its positive effects. However, every good language teacher desires that his learners make efforts to communicate in the language that they are being taught. This of course does not exclude the prerogative of the teacher himself to encourage and motivate the learners into speaking, while creating a positive and supportive ambiance that will make them have the desire to communicate in the target language. The teacher should do his best to bring learners to the level where he can freely communicate with native speakers of the target language in any given situation. Above all, the teacher should be patient with especially the very timid students as this will help to 
inspire and build up their confidence.

\section{Recommendation}

Based on the findings of this study, it is therefore recommended that teachers of French language use the communicative language teaching approach to build confidence in their students as this will help to develop faster their linguistic skills, given that this approach gives priority to listening and speaking skills over reading and writing skills.

\section{References}

Adesola, M. O. (2007). Pour un apprentissage du français langue étrangère comme langue de communication. $\quad L a$ Revue d'Etudes Française d'Ilorin (REFI), Ilorin Journal of French Studies, 1(1), 129-138.

Ajiboye, T., \& Oshounniran, T. (2010). Les particularités de l'oral et de l'écrit en français. In T. Ajiboye (Ed.), Linguistique et applications pédagogiques regards sur le français langue étrangère (pp. 91 - 104). Ibadan: Clean Slate Publishers.

Anderson, S. (2018). Is speech really more important than writing? A study of spoken and written language in society. Journal of Global Media Studies, 22, 97-102.

Araromi, M. (2009). The teaching of French in Nigeria: Historical panorama, pedagogical consideration and motivational strategies. An inaugural lecture delivered at the University of Ibadan. Nigeria: Ibadan University Press.

Aslim, V. (2011). Internet pour l'approche communicative? Retrieved 12 May, 2019 from www.researchgate.net

Axell, K. (2007). L'importance de la motivation pour apprendre une langue étrangère - la langue française dans un contexte scolaire. Unpublished master's thesis, Institutionen för humaniora. VÄXJÖ UNIVERSITET. Retrieved from http://nu.diva-portal.org/smash/get/diva2:204837/FULLTEXT01.pdf

Babayiğit, S. (2012). The role of oral language skill in reading and listening comprehension of text: a comparison of monolingual (L1) and bilingual (L2) speakers of English language. Journal of Research in Reading, 37(S1), S22-S47. https://doi.org/10.1111/j.1467-9817.2012.01538.x

Balogun, T. A. (2016). L'émergence des typologies des méthodes ou approches pour enseigner le français langue étrangère: comment se décrocher? Journal of Modern European Languages and Literatures, 5(1), 192-206.

Bello, J. Y. (1982). Basic principles of teaching. Ibadan: John Wiley \& Sons and Spectrum books Ltd.

Bérard, E. (1991). L'approche communicative. Paris : CLE International.

Burns, A., \& Seidlhofer, B. (2013). Speaking and pronunciation. In N. Schmitt (Ed.), An introduction to applied linguistics (2nd edition, pp. 197-214), London: Routledge.

Cambridge International Dictionary of English. (1995). Cambridge, England: Cambridge University Press.

Courtillon, J. (2006). Les conditions d'application de l'approche communicative. Revue Japonaise de Didactique du Français, Etudes Francophones, 1(1), 12-32.

Darancik, Y. (2018). Students' views on language skills in foreign language teaching. International Education Studies, 11(7), 166-178. https://doi.org/10.5539/ies.v11n7p166

David, J. (1975). French in Africa, a guide to the teaching of French as a foreign language. United Kingdom: Evans Brothers Ltd/UNESCO.

Denkci Akkas, F., \& Coker, B. (2016). The use of communicative approach in 9th Grade EFL classes. Eurasian Journal of Educational Research, 65, 71-90. https://doi.org/10.14689/ejer.2016.65.05

Dişlen, G. (2013). The Reasons of Lack of Motivation from the Students' and Teachers' Voices. Akademik Sosyal Araştirmalar Dergisi. The Journal of Academic Social Science, 1(1), 35-45. https://doi.org/10.16992/ASOS.13

Emordi, F. I. (2000). Le devenir du français en Afrique anglophone : le cas de l'enseignement du français au Nigéria. Ibadan Journal of European Studies, 1, 117-131.

Fattah, A., \& Saidalvi, A. (2019). The implementation of communicative language teaching by Iraqi English language teachers. International Journal of Engineering and Advanced Technology, 8, 1140-1147. 
https://doi.org/10.35940/ijeat.E1159.0585C19

Idogho, J. A. (2016). Towards a student-centred learning in Nigerian schools: drama-in-education and progressive pedagogy. Retrieved 10 January, 2020 from https://www.ajol.infoindex.phpcajtmsarticleviewFile

Isakova, A. (2018). Communicative approach to interactive foreign language lesson at university. SHS web of conferences 50, 01071. Retrieved 7 January, 2020 from https://doi.org/10.1051/shsconf/20185001071

Johnson, B. (2012). Motivation and attitudes toward learning French in the university's foreign language classroom. Theses. Paper 867. Retrieved from https://core.ac.uk/download/pdf/60553912.pdf

Ketch, A. (2005). Conversation: the comprehension connection. The Reading Teacher, 59(1), 8-13. https://doi.org/10.1598/RT.59.1.2

Kezie-Osuagwu, C. (2013). French as a foreign language: A summary of methodologies for teacher training development. South West Journal of Teacher Education, 5, 353-356.

Kezie-Osuagwu, C. (2017). Elaboration de fiche pedagogique a travers la methode communicative. In A. Sanya (Ed.), Issues in languages and literature in education (pp. 177-190). Nigeria: Pallestpat Konsepts.

Lai, H-Y. T. (2013). The motivation of learners of English as a foreign language revisited. International Education Studies, 6(10), 90-101. http://dx.doi.org/10.5539/ies.v6n10p90

Martinet, A. (1974). Langue parlée et code écrit : de la théorie linguistique à l'enseignement de la langue. France: Presses Universitaires de France.

Merriam-Webster Dictionary. (2017). Merriam-Webster Incorporated. Retrieved 10 May, 2019 from https://www.merriam-webster.com/.../

National Commission for Colleges of Education. (2012). Nigeria certificate in education minimum standards for languages. Abuja: NCCE.

Owoeye, S. T. (2010). Cognition, private speech and oral expression: implications for Nigerian learners of French. Kaduna State University Journal of French, 1(1), 313-328.

Richards, J. C. (2006). Communicative language teaching today. New York: Cambridge University Press.

Schmitt, N., \& Celce-murcia, M. (2013). An overview of applied linguistics. In N. Schmitt (Ed.), An introduction to applied linguistics (pp. 71-87). Milton Park, USA: Routledge.

Simire, G. (2005). Le français dans les universités nigérianes ... oui mais qui sont les apprenants ? RENEF, 1(8), $11-31$.

Spencer-Oatey, H., \& Žegarac, V. (2013). Pragmatics. In N. Schmitt (Ed.), An Introduction to Applied Linguistics (pp. 1-15). Routledge: Milton Park, USA.

Stein, M. (May, 1999). The bridge: from research to practice, developing oral proficiency in the immersion classroom. ACIE Newsletter, 1-5. Retrieved 26 February, 2017 from carla.umn.edu/immersion/.../Bridge

Swanson, P., \& Schlig, C. (2010). Improving second language speaking proficiency via interactional feedback. International Journal of Adult Vocational Education and Technology, 1(4), 17-30. https://doi.org/10.4018/javet.2010100102

Wells, G. (2007). Semiotic meditation, dialogue and the construction of knowledge. Human Development, 50(5), 244-274.

Zhang, B. (2013). An analysis of spoken language and written language and how they affect English language learning and teaching. Journal of Language Teaching and Research, 4(4), 834-838. 